\title{
The Role of Microfinance Institution for Poverty Reduction in Ethiopia
}

\author{
Yaregal Tilahun Geremewe \\ Department of Agricultural Economics and Natural Resource, Mizan Tepi University, Mizan Tepi, Ethiopia
}

\begin{abstract}
Micro finance institutions are basically set up with the goal of poverty alleviation. These institutions have a very important and effective role in both developed and in developing countries because it is considered the backbone of their economies. This indicates that without the establishment of micro finance institutions, no developing nation can achieve a viable economic growth/development or the reduction of poverty since they lack enough amount of money. Micro finance institutions can play a role in reduction of poverty and improving the socioeconomic condition of the poor since there is a positive contribution of micro finance institution and social development, in which there is better access to health, education and basic services and greater social respect. The contribution of education level and entrepreneurial skills has positive impact to poverty reduction in which there is increase in income, better living conditions and better access to basic needs. This review examines on the role of micro finance institutions for poverty reduction and the challenges on the performance of operating micro finance institution. The review result suggest that major problems that faces the micro finance institution in order to take and operate their business are absence of training for borrowers, weak monitoring and support system, high interest rate, uncomfortable loan repayment schedule, loan size, loan capital shortage, lack of use of technology and cost effective methods, human resource problem, lack of access to credit, insufficient support from government, limited management capacity of microfinance institutions, less attraction on financial sustainability, improper regulations, and limited management capacity of micro finance institutions.
\end{abstract}

Keywords: MFIs, poverty, role of MFIs, problems on performance, poverty reduction

DOI: $10.7176 / \mathrm{JESD} / 10-5-04$

Publication date:March $31^{\text {st }} 2019$

\section{INTRODUCTION}

\subsection{Background}

Microfinance institutions are found among the institutions which provide different financial service for the poor who are out of the conventional banking system particularly in developing countries. It provides financial services to poor clients who in most cases have no access to formal financial institutions. During the last three decades, microfinance has captured the interest of both academics and policy makers. This is, among other things, due to the success of the industry (Assefa et al., 2013).

Micro-finance institutions is expanding credit to rural and urban entrepreneurs, as well as, in achieving food for both rural and urban poor section of the people and thereby it has irreplaceable role to reduce poverty in developing countries. Moreover, it characterized by rapid growth, an aggressive drive to achieve scale, a broad geographic coverage, a dominance of government backed Microfinance Institutions (MFIs), an emphasis on rural households, the promotion of both credit and savings products, a strong focus on sustainability and by the fact that the sector is Ethiopian owned and driven (Ebisa et al., 2013).

Microfinance is an institution that provides the poor with savings, credit and insurance facilities with the objective of setting up or expanding income generating activities. It aims at household income security and hence has a broader aim than the simple provision of micro credit (Rajasekhar, 2004). In addition, microfinance institutions also provide entrepreneur, business management, marketing and financial management related support services and trainings to their beneficiaries (Aghion and Morduch, 2004). Microfinance institutions encourage their members/beneficiaries to save and as their saving balance grows more the loan balance they can access become higher. This way, microfinance helps poor households diversify their income, acquire more assets and improve their lifestyle and mainly focused in poverty reduction (Ledgerwood, 2002).

Ebisa et al. (2013) found that microfinance institutions are decisive way outs from the vicious circle of poverty particularly for the rural and urban poor, particularly in a country like Ethiopia where many people live barely below the absolute poverty line. The micro financing industry of Ethiopia is escalating in the face of the growing deep concerns for inflation and low interest rate in the microfinance industry affecting the financial health and viability of MFIs.

Muluken and Mesfin (2014) revealed that, factors related to clients includes: problems related to the repayment, diversion of loan into non income generating activities, business condition of the borrowers; institutional factors such as shortage of human resource, lack of cost effective technologies, shortage of loan capital and some others are identified and political factors which are related to MFIs performance are also recognized as challenges affects the performance of microfinance institutions. Not only this but also one of the 
bottlenecks in improving the wellbeing of the poor people in developing and under developed poor countries is lack of access to credit from formal financial institutes that invariably requires collateral (Schreiner, 2002). Most, if not all, of the loan available to the poor in such developing countries is obtained either from family, friends or informal money lenders. When the poor resorts to get loans from informal credit providers such as money lenders, business men and pawn brokers, they are usually charged a very high interest rates and forced to handover whatever valuable items they may possess as collateral which in the case of failure to pay may not be collected back; and this may lead them to a worse than their pre-loan situation (Gosa, 2014).

Providing small loans through microfinance institutions is taken as a means to efforts against poverty. Wolday (2003) indicated that microfinance institutions are considered as one of the important tools of reaching the poor who had no or very limited access to credit from the traditional financial sector. To enhance the poor's access to credit in Ethiopia and to promote microfinance institutions growth the government issued proclamation No. 40/1996 the microfinance law. This assisted in increasing the number of microfinance institutions operating in the country to 31 as of May, 2012 from twenty- six, as of November 2005 (NBE, 2012). However, despite the encouraging increase in number of microfinance institutions in the country, the rural poor's' demand for credit remained untouched particularly due to the institutions bureaucratic procedures and methodologies (Abu, 2015). Adam Smith in his famous book "The Wealth of Nations" said, "Money, says the proverb, makes money. When you have got a little, it is often easy to get more. The great difficulty is to get that little" (Hulme, 2000).

Microfinance has been renowned, globally, as a feasible and sustainable tool for poverty reduction and economic development through improving income generating activities and employment creations. Despite well documented evidence of the positive impact of promoting access to finance to under-served segments of the community, many poor people in Africa still remain excluded from the mainstreaming financial systems (Arega, 2016).

In Ethiopia, the potential demand for financial services, particularly micro-credits is huge. However, the existing supply of financial services to the poor is very limited. As a strategic tool in alleviating the problem, though provision of microfinance services by government and non-government organizations were started in the past years, much emphasis was not given until the recent years. However, recently, the paradigm shift in reaching and mobilizing the poor is attaining greater attention both at the national and international levels. By virtue of these, besides strengthening the effort of both parties, the recent phenomenon is the establishment of formal micro-financing institutions which operate in the country.

Even if there are so many researchers which study on roles for reducing poverty and challenges which hinder on the expansion of microfinance institution for poverty alleviation, employment creation and socio economic growth of the country. Due to those constraints, the MFIs development is not diversified as of their roles in the country. So it is vital to review on these problems which face the creation and set-up of MFIs and the contribution of microfinance institutions in the economy to reduce poverty.

The general objective of this review is to the role of microfinance institution for poverty reduction in Ethiopia. The specific objectives of the review were:

1. To review the contribution of MFIs in poverty reduction.

2. To review major factors which affect the performance of MFIs.

\section{REVIEW OF RELATED LITERATURE}

\subsection{What is Microfinance?}

Microfinance is the form of provision of a broad range of financial services to low- income micro enterprises and households. It is a form of financial development that has primarily focused on alleviating poverty through providing financial services to the poor (Michael, 2005). Microfinance is the supply of loans, savings, money transfers, insurance, and other financial services to low-income people. Microfinance institutions (MFIs) which encompass a wide range of providers that vary in legal structure, mission, and methodology offer these financial services to clients who do not have access to mainstream banks or other formal financial service providers (Lafourcade et al., 2005).

Similarly, Parker et al. (2000) defines microfinance as provision of small loans (called "micro-credit") or savings services for people excluded from the formal banking system. Microfinance is a type of banking service which provides access to financial and non-financial services to low income or unemployed people. Microfinance is a powerful tool to self-empower the poor people especially women at world level and especially in developing countries (Noreen, 2011).

The definitions of microfinance given by different scholars contain some similar pointes. They describe microfinance as provision of a small amount of loan for the poor, specifically the rural poor living in developing country. Some microfinance institutions provide non-financial services for their clients. But in our case, most of the micro finances are known by the provision of a small amount of credit and saving services (Muluken and Mesfin, 2014). 


\subsection{Definition of Poverty}

The word poverty comes from old French poverté (Modern French: pauvreté), from Latin paupertās from pauper (poor) (Walter, 2005). There are several definitions of poverty depending on the context of the situation it is placed in. According to United nation, fundamentally, poverty is the inability of having choices and opportunities, a violation of human dignity. It means lack of basic capacity to participate effectively in society. It means not having enough to feed and clothe a family, not having a school or clinic to go to, not having the land on which to grow one's food or a job to earn one's living, not having access to credit (Gordon, 2005). According to World Bank, Poverty is pronounced deprivation in well-being, and comprises many dimensions. It includes low incomes and the inability to acquire the basic goods and services necessary for survival with dignity. Poverty also encompasses low levels of health and education, poor access to clean water and sanitation, inadequate physical security, lack of voice, and insufficient capacity and opportunity to better one's life (Tesfaye, 20104).

Poverty is a condition in which people lack satisfactory material resources (food, shelter, clothing, housing), are unable to access basic services (health, education, water, sanitation), and are constrained in their ability to exercise rights, share power and lend their voices to the institutions and processes which affect the social, economic and political environments in which they live and work (Siyum, 2015). According to Ukwu (2002), suggests that poverty is a living condition in which an entity or individual is faced with economic, social, political, cultural and environmental deprivations. These deprivations are captured as lack of food, poor expectancy rate, poor environmental conditions, low educational opportunity, poor health services, general lack of economic infrastructure and lack of active participation in decision making either as it affects the individual or a nation.

There are different types of poverty such as income poverty, absolute poverty, and relative poverty and consistent poverty (Ebimobowei et al., 2012). Income poverty is type of poverty that is a result of lack of money or limited income while absolute poverty is a type of poverty where people are starved, living without proper housing, clothing or medical care- people who struggle to stay alive. Relative poverty is a type of poverty where people are considered to be living substantially less than the general standard of living in the society. Consistent poverty is a type of poverty that is the combination of income poverty and deprivation (Ibok, 2009, Momoh, 2005, Khandker, 2003). Consequently, microfinance has proved to be a powerful instrument for poverty reduction that enables the poor to build assets, increase incomes and reduce their vulnerability to economic stress (Ebimobowei et al., 2012)

\subsection{Microfinance Institutions in Ethiopia}

The development of microfinance institutions in Ethiopia is a recent phenomenon. But it has a long history in different forms. The proclamation, which provides for the establishment of microfinance institutions, was issued in July 1996. Since then, various microfinance institutions have legally been registered and started delivering microfinance services (Wolday, 2000). The number of micro finance institutions as well as the number of clients is increasing from time to time. The existing political and economical condition of the country contributes a lot for the development of the microfinance industry.

The decision of the government of Ethiopia to liberalize and restructure the financial sector in the 1990s had a significant impact on the growth of MFIs. Ethiopia laid down a legal framework for microfinance institutions (MFIs) by proclamation No. 40/96. The issuance of this proclamation is seen as an important breakthrough followed by a number of regulatory directives and policies that help to protect and ensure the prudential safety of Microfinance institutions. Similar to Banks, MFIs service provision also involve public property in the form of savings and credit that requires supervision and regulation of the activities of MFIs by the state with a view to ensuring sustainability and protection of depositors interest (Hailu, 2006). Following the enactment of this proclamation, several micro credit programs that were previously operated by non-governmental organizations or various central and regional government departments were transformed in to licensed microfinance institutions subject to regulation and supervision. The institutional set up and operational procedures of the Ethiopian MFIs are the direct copy of Grameen Bank's mode and group lending practice is widely used.

\subsection{The Need for Microfinance}

Microfinance institutions play many roles in the development process. The need for microfinance is also increasing in many countries. According to (Parker et al., 2000), in the right environments, microfinance can accomplish many roles such as financer people's economic choices, diversifying household income, making household less vulnerable to downturn in the economy or personal, smoothening income flows of the household, improve quality of life throughout the year and strengthen the economic position of women so that they can take greater control of decisions and events in their lives. In addition to this MF contributes in the process of household asset building. It also provides savings service, allowing poor households to accumulate safe, but flexible cash accounts to draw on when needed. 
Microfinance is a type of banking service which provides access to financial and non-financial services to low income or unemployed people. Microfinance is a powerful tool to self-empower the poor people especially women at world level and especially in developing countries (Noreen, 2011). It involves the provision of financial services such as savings, loans and insurance to poor people living in both urban and rural settings who are unable to obtain such services from the formal financial sector. Micro finance in achieving the Millennium Development Goals of eradication of poverty and hunger, achieve universal education, promote gender equality and empower women; reduce child mortality; improve maternal health; combat HIV/AIDS, malaria and other diseases; ensure environmental sustainability; and develop a global partnership for development (Ebimobowei, et al., 2012)

\subsection{Approaches of MFIs}

There are different approaches to microfinance service provision to the poor. According to Robinson (2001), the most known approaches in microfinance development can be categorized poverty lending vs. financial system approach and business vs. developmental approach.

\subsubsection{Poverty Lending Vs Financial System Approach}

Both approaches share the goal of making financial services available to poor people throughout the world. However, the poverty lending approach focuses on poverty reduction through credit and other services provided by institutions that are funded by donor and government subsidies. A primary goal of this approach is to reach the poor especially the poorest of the poor with credit. Saving is not a significant part of this approach. The poverty lending approach was first realized in Grameen bank in Bangladesh. It has wide outreach to poor borrowers. But the approach has required large amount of continuing subsidies and does not meet poor people's demand for saving services. Due to these it has not proven a globally affordable model (Robinson, 2001). With the failure of credit institutions to address the grassroots (households') financial needs, the situation demanded an innovative approach to address the lower segment of the population. The new approach should correct the drawbacks of the old approach (Ayelech, 2011). The financial system approach focuses on commercial financial intermediation among poor borrowers and savers; and also emphasis is given to institutional self-sufficiency. The approach targets lending to the economically active poor people, i.e. people with the ability to use small loans for income activities and the willingness to repay and to voluntary make required savings.

\subsubsection{Business Vs Development Approach}

The first objective of MFIs is the provision of basic financial services to the poor. However, the service provision depends on their approaches. There are two contesting approaches among microfinance supporters: business approach and development approach. According to Ayelech (2010), business approach primarily focused on organizational achievements such as repayment, cost recovery and profitability. Hence, their concern is =how to develop the industry rather than how to develop the community.

On the other side, development approach emphasis more on how the client is doing rather than profitability. Supporters of this approach argue that the client should participate in awareness and capacity building programs before taking their loans. Therefore, the development approach gives emphasis not only to building institutions for sustainable provision of services, but also empowering the poor people to get the most out of the services delivered; this study adopts the development approach to assess the functioning of OMFI and to see how the institution incorporate its financial services with other non-financial services in the area.

\subsection{Microfinance and Its Impact on Poverty}

The poor section of peoples has low income, which leads to low investment and which in turn leads to low productivity. Microfinance institutions, saving and credit cooperatives should be designed to responds to the failure of the commercial and development banks to meet the financial needs of poor and small producers (Adebayo, 2009, Fiona, 1999). Microfinance institutions directly affect household income by encouraging productivity. It also increases diversity of production and productivity, as well as, maximize the utilization of available resources and to exploit their comparative advantage within market places. Furthermore, it encourages the socio-economic development of the concerned society (Ahmed et al., 2011). It helps farmers to invest in large agriculture technology, such as high yielding seeds and mineral fertilizer that increase income. Thus, it is possible to argue that micro finance is the most strategies that should be employed to eradicate poverty. It is coined as the financial service rendered to the deprived group of the people and small entrepreneurs to help them in developing self-employment opportunities and income generating activities (Ebimobowei et al., 2012).

Microfinance is the provision of financial services to poor and low income households without access to formal financial institutions. Besides it is a strategy for providing to the poor in rural and urban areas, especially women with savings and credit facilities to set up or expand business, and increase household security (Wolday, 2002). This implies that it involves the provision of financial services such as savings, loans and insurance to poor people living in both urban and rural settings who are unable to obtain such services from the formal financial sector. It is possible to argue that microfinance provides a window of opportunity for the poor to access 
a borrowing and saving facility. In other countries, these facilities also provide organizational help, training, safety nets, empowerment, and financial and other help during crises.

Microfinance programs target both economic and social poverty. To assess the success of their efforts microfinance institutions need to measure the impact on the borrowers. The primary objective of all MFIs interventions is poverty reduction. Poverty reduction is perceived from the economic point of view. On the other hand, MFIs interventions promote living condition of poor people by offering supportive service. These supportive services like access to health and education services are important indicators of human development. The objective of the program is to create sustainable changes in the lives and livelihood of the poor in particular (Meyer, 2002).

Generally microfinance institutions are judged by the positive impact that they have to bring in terms of improving the income as well as living condition of its target beneficiaries and ultimately in terms of their role towards reducing poverty. It is generally believed that microfinance programs will raise incomes and broaden financial markets by mainly providing credit, among other services to small scale entrepreneurs (Aghion and Morduch, 2000). By providing small loans MFIs help the poor to better cope with risk, to take advantage of income generating opportunities and to reduce vulnerability (Paxton and Cuevas, 2001).

\subsection{Factors Affecting the Performance of Microfinance Institutions}

Most microfinance programs are small and vulnerable to resource constraints. Most operate in a few locations and serve specific clusters of clients, so they are exposed to the systematic risks of undiversified loan portfolios. Most mobilize few savings and not financially self-sufficient, so they are dependent on the fads of donors and government for their future existence (Meyer, 2002). Microfinance institutions may face financial problems which affect their performance. Huang (2005) distinguishes three groups of factors: policy, geographical and institutional factors.

Policy Factors: There are different macro-economic factors related to MFIs. The first factor is the income level. Westley (2005) states that regions with higher levels of income have less developed microfinance sectors. He provides two reasons. Firstly, micro-entrepreneurs with higher incomes have more opportunities to self-finance through savings. Secondly, they may benefit more easily from informal finance through family and friends, as well as from formal finance.

Similarly, Schreiner and Colombet (2001) argue that one of the reasons why microfinance in Argentina has not developed is due to the higher wages people earn. Traditionally, microfinance also focuses on the poor excluded clients, so microfinance should be reaching more clients in regions that are poor. The other factor is economic instability of the country. Microfinance is more developed in countries that have relatively in stable economies. The international donor community has historically played an important role in subsidizing the emergence and further development of microfinance programs.

Geographic Variables: Stieglitz and Weiss (1981) stated that transaction and information costs influence financial development. In some cases, they lead to market failures. Good interconnectivity between regions, the availability of electricity, communications and sanitation networks lower these costs. A high population density also helps. According to Sriram and Kumar (2005) stated that two contradictory arguments could be made. The first is that formal financial institutions may be more developed in regions with higher population density and good regional interconnectivity. Thus the need for specific MFIs may not be present. The second is that, if the development of the two sectors is complementary, these factors could eventually also stimulate the development of the microfinance sector.

Institutional Variables: Institutions play an important role in the development process of a country. One institution that is often mentioned in the microfinance literature is the educational system. The role of human capital in financial sector development is widely recognized (Vanroose, 2008). Paulson (2002) of his finding stated that regions with higher levels of education have more developed financial systems.

\subsection{Empirical Review on MFIs Activities and Poverty}

2.7.1. Contribution of MFIs for poverty reduction and factors affecting MFIs performance

Many studies were conducted on the issue related to microfinance institutions performance, challenges their impact on the economic and social condition of the rural poor. The study conducted by Ebisa et al. (2013), shows that the mean amount of loans extended by 30 microfinance institutions in the country is 2.2938 , whereas the mean borrowing customers equal an amount of 8.2434. As it is indicated in this study the $\mathrm{R}$ square value is 0.913 implying that $91.3 \%$ of the variations in the amount of loans extended by 30 microfinance institutions in the country are explained by the number of borrowing clients. On the other hand, the Pearson correlation indicates strong positive linear relationships between number of borrowing clients and amount of loans extended. The total number of active borrowing clients of the microfinance institutions in Ethiopia reached over 2.4 million customers in 2011 whereas the total credit extended by all microfinance institutions amounted to Birr 6.9 billion. Of the total credit granted, the share of the three largest Microfinance institutions is Birr 5.1 billion. 
Khandker (1999) argued whether participation in micro-credit programs does in fact reduce poverty in terms of consumption and help increase income and employment on a sustained basis could be measured directly. The benefits of program participation can also be measured indirectly, by measuring changes in socio-economic outcomes. This implies that the effects of micro-credit programs on participants can be measured in terms of consumption, nutrition, employment, net worth, schooling, contraceptive use and fertility. The study argued that changes in income and employment among program participants might affect the living standard of the poor. There are two important factors that determine the overall impact of the program. These are the growth potential of activities financed by the micro credit programs and the extent of credit market imperfections that are resolved with enhanced availability of credit.

Irobi (2008) investigated microfinance and poverty alleviation in Nigeria, the study employed questionnaire in data collection and found that microfinance intervention has a positive impact on alleviation of poverty among the women of this association. Interestingly, this study found that most women in this association experienced increased income and therefore, improved their economic status, political and social conditions after receiving the loans. While James (2005), examined impact of microfinance on poverty alleviation in Nigeria: The paper used chi-square test, F-test and T-test. The findings revealed that there is a significant difference between those people who used microfinance institutions and those who do not use them. There is a significant effect of microfinance institutions in alleviating poverty by increasing income and changing economic status of those who patronize them. Their study concludes that microfinance institution is indeed a potent strategy of poverty reduction and a viable tool for providing credit to the poor.

Birhanu (2015) revealed that Microfinance has enabled the clients to generate income that could be spent on better facilities, which could improve the living standard of clients. Clients have got more chance of getting meals per day than non-clients. The result indicates that more clients have enjoyed diet improvement than nonclients. Clients have got more chance of improving their diet in comparison to non-clients. Considering schoolage children and actual enrollment, the result does not show significant difference between the two groups. The program has improved ability of clients to respond the demand for medical care. The study found difference in responsiveness of demand for medical care between the two groups. Microfinance program improves job opportunities. It creates and expands business activities.

More optimistic deductions in terms of the ability of microfinance to reduce vulnerability are found in Indonesia by Gertler et al. (2003), who revealed that access to finance enables families' smooth consumption in the face of declines in the health of adult family members. By establishing an empirical relationship between health condition and consumption the authors test for a relation between access to a financial institution and consumption shortfalls associated with ill-health. Using geographic distance as a measure of access, they find that for households in an area with a BRI branch, health shocks have no effect on consumption. However, this study does not differentiate within the group of the poor. Generally microfinance institutions are judged by the positive impact that they have to bring in terms of improving the income as well as living condition of its target beneficiaries and ultimately in terms of their role towards reducing poverty. It is generally believed that microfinance programs will raise incomes and broaden financial markets by mainly providing credit, among other services to small scale entrepreneurs.

Tassew (2004) in his study in Tigray indicated that Ethiopia has started giving attention to the establishment of MFIs in rural areas so as to help the poor get access to financial resources. He pointed out that the important consideration before providing credit to the poor is to examine whether the key factor for the poor to get out of their problem is finance. In this study, which was conducted in 35 watersheds in central Tigray, he showed that the most important and profitable activities the poor can engage within the existing micro-credit systems are petty trading, goat fattening, poultry and chicken farming. As far as oxen and goat fattening is concerned, there is a higher positive return to both labor and capital. The return to capital is, of course, higher than the return to labor according to this study. Therefore, finance is required for these activities and thereby to reduce poverty in the study area. This, however, depends on the price of livestock.

Shastri (2009) revealed that there is no way better than micro finance in the war against poverty. Creating self-employment opportunities is one way of attacking poverty and solving the problems of unemployment. The authors reported that there are over 24 core people below the poverty line in India. The Scheme of Micro-finance has been found as an effective instrument for lifting the poor above the level of poverty by providing them selfemployment opportunities and making them credit worthy. And Marguerite (2000) pointed out that microfinance institutions are important for poor people in providing credit and mobilizing of savings. MFI can expand and diversify enterprises and helps to reduce risk, improve management, raise product, helps in increase household's income and provide credit at much lower cost than credit from informal commercial moneylenders.

Mawa (2008) conducted a research study focusing the issue under discussion and concluded that microfinance is an innovative step towards alleviating poverty. The author mentioned that microfinance facilities provided to the people help them to use and develop their skills and enable them to earn money through micro enterprises. Moreover provision of micro finance helps them to smooth their consumption level and manage 
unexpected risks. Micro finance helps the poor to built assets, educate their children and have a better quality of life

Wolday (2000) from his study of all MFIs in Ethiopia found that MFIs in Ethiopia have shown that significant improvement in terms of loan outstanding and savings. The clientele served by the MFIs in Ethiopia are mainly the rural poor. About 44 percent of the clients of MFIs in Ethiopia are female, relatively higher out reach of MFIs by all standards of measurement. The two governments supported MFIs are ACSI and DECSI, which account for $80 \%$ of total clients in the industry. MFIs in Ethiopia have high repayment rate, which varies from $94 \%$ to $100 \%$.

Ebisa et al. (2013) revealed that lack of skilled personnel is the common problem in Ethiopian Microfinance Institutions. This situation is more exacerbated by high turnover of experienced personnel either for the need for better jobs or hate to work in rural areas with minimal facilities provided as compared to urban areas which offer better living conditions. There is also a problem of using modern core finance technologies for many of MFIs specially those microfinance institutions operating in remote rural areas having poor infrastructure development. As a result, there are problems of non-standardized reporting and performance monitoring system. On the other hand, MFIs face challenges of obtaining loans in the existing financial market, particularly from banks, which hampers strive for addressing various needs of clients

According to Muhammad (2010), focus on the challenges and opportunities face microfinance sector in Pakistan, his study resulted that numerous challenges are ahead of microfinance sector like improper regulations, increasing competition, innovative and diversified products, profitability, stability, limited management capacity of micro finance institutions (MFIs). Dahir (2015) in his study on the challenges facing microfinance institutions in poverty eradication in Mogadishu, he found that the major challenges that face microfinance institutions range from default risk inherited from borrowers and lack of understanding the concept of microfinance by the clients to inadequate donor funding where the microfinance institutions do not have enough adequate capital from donor to meet the needs of the microfinance beneficiaries in order to help those who need assistance of the microfinance. On the other hand, the challenges facing microfinance institutions include insufficient support from government. Other challenges include insufficient support from government, limited management capacity of microfinance institutions, less attraction on financial sustainability of MFIs and lack of adequate loan or equity capital to increase loan-able funds.

Elly (2015) also studied on the role of MFIs for poverty reduction and revealed that there is a positive contribution of microfinance institutions to the social development, in which there is better access to health, education and basic services and greater social respect. The contribution of education level and entrepreneurial skills has positive impact to poverty reduction. From the finding obtained it has been found that microfinance institutions has a positive impact to poverty reduction in which there is increase in income, better living conditions and better access to basic needs. Lastly study found that challenges facing entrepreneurs are short time for loan repayment, low amount offered by MFIs, expensive collaterals and high interest rates.

\section{SUMMERY AND CONCLUSION}

Poverty has remained to be a daunting challenge to developing countries. It is a problem for all the countries irrespective of their level of development and can be observed in many forms. It has both income and non income dimensions. It may be a lack of income or resources, a lack of coping capacity, a lack of basic human capabilities, a lack of institutional defenses or in extreme cases a lack of all of these. In a wider sense, it may be a combination of economic, social and political deprivations. To address this problem different strategies have been implemented by developing countries depending on their existing situations. So based on this problem Ethiopia use micro finance institutions and extend it for give small loans to poor people aiming at enhancing self - employment projects that generate income to improve the living conditions of the poor and alleviate poverty. Because micro finance institutions are generally regarded as the engine of economic growth and development, poverty reduction and equitable income distribution in developing economies like Ethiopia.

Micro finance institutions should increase the loan size. Increasing the loan size will attract the better-off clients and, therefore, ultimately results in a mission drift. It has enabled the clients to generate income that could be spent on better facilities, which could improve the living standard of clients. However, MFIs in Ethiopia should not have to concentrate on large loan size at the expense of their social mission. Instead, institutions are advised to adapt other strategies like charging relatively high interest rate, making productive use of loan officers, keeping operating costs to minimum level, encouraging voluntary savings and diversification of income sources. Regarding impact on poverty, in addition to boosting household income and enterprise profit, microfinance loans help current urban and rural clients in financing household welfare (like food, health and education, clothing, and the likes). Loans also help poor families smooth out income fluctuations and maintain consumption levels even during the hungry seasons. Therefore, one can conclude that with the help of the financial services they obtained from the MFIs, a significant number of clients have been able to increase their income and buffered themselves from the difficulties of vulnerability. 
Even if MFIs are contributing a lot for poverty alleviation, there are problems which hinder for the expansion of micro finance institutions. These are: Absence of training for borrowers, weak monitoring and support system, interest rate of micro finance institutions, uncomfortable loan repayment schedule, loan size, loan capital shortage, training provision to employees and clients, lack of use of technology and cost effective methods, human resource problem, loan capital problem, lack of strong loan collection system in the institutions, lack of access to credit, insufficient support from government, limited management capacity of microfinance institutions, less attraction on financial sustainability of MFIs and lack of adequate loan or equity capital to increase loan-able funds, improper regulations, increasing competition, innovative and diversified products, profitability, stability, limited management capacity of micro finance institutions.

Generally, now a day MFIs are widely recognized as the most reliable economic development and growth, poverty reduction, income generation and employment creation. MFIs occupy prominent position in order to achieve the above objective in Ethiopia. So without MFIs no developing nation can achieve a viable economic growth and reduction of poverty since their income is so low. So attention should be given to these problems in order to improve the establishment and role of MFIs for poverty alleviation.

\section{REFERENCES}

Abu Girma (2013). The Challenges and Policies of Poverty Reduction in Ethiopia Vol 5, No 1 Ethiopian ejournal for research and innovation. ADB Research Institute

Adebayo, A. A. (2009). "Theoretical Perspectives on Poverty Reduction: Challenges for Policy in Nigeria". 8(2) pp. 34-43.

Aghion and Morduch. (2004). The Economics of Microfinacne. MIT Press.

Aghion, B. A. de \& Morduch, J. (2000), 'Microfinance beyond group lending', Economics of Transition, 8(2), pp. 401-420.

Ahmad, Shafiq, Durrani, Muhammad Kashif Khan, Malik, Muhammad Imran, Usman, Abid (2011). "Role of Micro Finance in Reducing Poverty: A Look at Social and Economic Factors". 2(21).

Arega Seyoum (2016). Performance of MFIs and Their Role in Poverty Alleviation: The Case of Selected MFIs in Ethiopia. International Journal of Scientific and Research Publications, 6 (2), ISSN 2250-3153.

Assefa, E., Hermes, N. \& Meesters, A. ( 2013). Competition and the performance of microfinance institutions. Applied Financial Economics, 23, 767-782.

Ayelech Eshete (2010). An assessment of the role of microfinance institutions in urban poverty alleviation: MA thesis Addis Ababa University Addis Ababa, Ethiopia

Birhanu Daba (2015). He Impact of Micro Finance on Poverty Reduction: A Case Study of Wasasa MicroFinancing Institution in East Showa Zone of Oromia Regional State, Ethiopia

Dilayehu Daniel (2014). The Role of Microfinance Institutions in Accessing Credit and Poverty Reduction in Rural Ethiopia: In the Case of Omo Micro Finance Institution in Damot Gale

Ebimobowei, Appah, Sophia, John Wisdom, Soreh (2012). "An Analysis of Microfinance and Poverty Reduction in Bayelsa State of Nigeria". 1(7).

Ebisa Deribie, Getachew Nigussie and Fikadu Mitiku (2013). "Filling the breach: Microfinance". Journal of Business and Economic Management. 1(1).

Fiona, Meehan (1999). "Impact of Micro Credit at household level Case study of Dedibit Credit and Saving Institutions".

Gertler, P., Levine, D. I. and Moreti, E. (2003), 'Do microfinance programs help families ensure consumption against illness?' Center for International Development Economics Research (CIDER), Working Paper No. C03-129, University of California, Berkeley.

Gordon, D. 2005. Indicators of poverty and hunger. In Expert Group meeting on youth development indicators, p. $12-14$.

Gosa Setu (2014). The Role of Microfinance Institutions in Poverty Reduction and Women's Empowerment in Ethiopia: The Case of Dedibit Credit and Saving Institution. Journal of Research on Humanities and Social Sciences, 4(16), 2224-5766

Hailu, L. (2006). Credit and risk management. AEMFI Conference proceeding on microfinance development in Ethiopia. Bahir Dar.

Hulme, D. (2000) Impact assessment methodologies for microfinance: Theory, experience and better practice: World Development, Vol. 28.

Ibok, E.E. and Mboho, S.K. (2009). "Women Organisations and Poverty Alliviation in Rural Communities in Nigeria: A Study of Akwa Ibom State"., 3(1) pp. 198-208.

Irobi, N. C. (2008). Microfinance and poverty alleviation: A case study of Obazu Progressive Women Association. Uppsala: Department of Economics.

James, Q. (2005). Financial Sector Assessment hand book. Washngton: World Bank.

Khandker, S.R. (2003). “Microfinance and Poverty: Evidence Using Panel Data from Bangladesh”. Retrieved 
on11/03/2014 from http://econ.worldbank.org.

Khandker, Shahidur (1999) Fighting Poverty with Micro credit. Experience in Bangladish, the University Press Limited, Bangladish.

Lafourcade, A. L., Isern, J., Mwangi, P. and Brown, M. (2005). Overview of the outreach and financial performance of microfinance institutions in Africa. Microfinance Information exchange, Washington DC.

Ledgerwood, J. (2002). Sustainable Banking with the Poor: an Institutional and Financial Perspective. Washington D.C.

Mawa, B. (2008). Impact of Micro-finance Towards Achieving Poverty Alleviation. Pakistan Journal of Social Sciences, 5 (9), 876-882.

Meyer, R. L. (2002). 'Track Record of Financial Institutions in Assisting the Poor in Asia'

Momoh, J. (2005). "The Role of Microfinance in Rural Poverty Reduction in Developing Countries". Retrieved on 11/03/2014 from http://www.wi.hswismar.discussion paper

Morduch Jonathan (2000) "The Microfinance Schism" in World Development Vol. 28 No. 4 Elsevier Science Ltd: Great Britain

Muhammad, S. (2011). Microfinance challenges and opportunities in Pakistan. European Journal of Social Sciences, 14(1).

Muluken Alemayehu and Mesfin Lemma (2014). Assessment of Factors Affecting the Performance of Microfinance Institutions: The Case of Hawassa City. Journal of Business and agricultural science, 6(1)

Noreen, S. (2011). Role of Microfinance in empowerment of female population of Bahawalpur District. International Conference on Economics and Finance Research, (2011). 318-324.

Parker, J., Singh, I. and Hattel, K. (2000). The role of microfinance in the fight against HIV/AIDS. Development Alternatives, Inc. (DAI), Bethesda, Maryland

Paxton, J., and Cuevas, C. E. (2001), 'Outreach and Sustainability of Member-Based Rural Financial Intermediaries', In Zeller, M., and R.L. Meyer (eds.) (2001): The Triangle of Microfinance: Financial Sustainability, Outreach and Impact. Washington D.C.: IFPRI / John Hopkins University Press.

Rajasekhar, D. (2004). Microfinance and Poverty alleviation:Issues related to NGO Programs in Western India. Institute for Social and Economic Change, 146. Reduction in Bayelsa State of Nigeria".

Robinson, M. (2001). The Microfinance Revolution: Sustainable Finance for the Poor:

Schreiner, M. (2002). Aspects of Outreach: A Framework for Discussin of the Social Benefits of Microfinance. Journal of International Development, Volume 14.

Shastri, R.K., (2009). Micro-finance and Poverty Reduction in India (A Comparative Study with Asian Countries). African Journal of Business Management, 136-140.

Siyum Menda. 2015. The role of micro and Small Scale Business Enterprises in Urban Poverty Alleviation: A Case Study on Cobble Stone Paving Sector in Addis Ababa City.

Tassew W/hanna (2004) The Impact of the Dedebit Credit and Savings Institution on Poverty Reduction and Community Development: A Paper presented in the International Conference on Microfinance Development in Ethiopia. January 21-23, 2004, Awassa, Ethiopia.

Tesfaye Tegegn. 2014. The role of micro and small enterprises in reducing youth unemployment: the case of Meserak TVET College graduates in Addis Ababa city administration.

Ukwu, U.I. 2002. Towards Effective Poverty Eradication Strategy. NCEMA Policy Analysis Series, 8(1), p.91108.

Vanroose, A. (2008). What macro factors make microfinance institutions reach out? Savings and Development, $153-174$

Walter, S. 2005. An Etymological Dictionary of the English Language. Dover Publications.

Washington, D.C. World Bank.

Wolday A. (2003) Microfinance in Ethiopia: Performance Challenges and Role in Poverty Reduction. Association of Microfinance Institutions. Occasional paper No. 7, AEMFI: Addis Ababa, Ethiopia.

Wolday Amha (2000). "Review of Microfinance Industry in Ethiopia, Regulatory Framework and Performance"., Addis Ababa. Woreda, Wolaita Zone. 1(7) 